\title{
SINO-RUSSIA NEXUS AND NEW COLD WAR IN EURASIA
}

\author{
Ahmad Ali ${ }^{*}$, Tajwer Ali ${ }^{\dagger}$ \& Haseena Sultan
}

\begin{abstract}
Cold war between US and Soviet Union ended in 1989 but Cold War between Russia and USA is still there. US-Soviet Cold war was in fact an indirect clash of ideologies, while the New Cold War between US and Russia is an indirect clash of hegemony and influence. USA considers itself the master of the Globe after the end of First Cold War and Russia does not accept the superiority of USA and practise all those Activities, which are mainly punished by super powers. Without the consent of US, Russia is cooperating with rogue states, it makes alliances, and it attacks small countries like Georgia and Ukraine. USA is busy in all those states which were previously part of Soviet Union like Central Asian Countries. This paper states that Cold war has not ended but it has taken a pause and again it has been started between Russia and USA. Glaring examples in this regards are formation of BRICS, SCO, EEC and NATO expansionism in Afghanistan and Iraq and US USSR involvement in Middle East.
\end{abstract}

Keywords: New Cold War; Cold War-II, China, Russia, Soviet Union, United States, First Cold War.

\section{Introduction}

Cold war does not need any proper declaration just like a hard war, it just begins as a result of huge competition between two nuclear States. Such phenonomenon of rivalry has been witnessed by the most recent history of the world. When a war does not need a proper declaration, then surely it would not be ended properly. The idea of the end of Cold War in 1989 is

\footnotetext{
Lecturer in Political Science, Higher Education Department, Khyber Pakhtoonkhwa Pakistan.

${ }^{\dagger}$ MPhil-IR graduate from IIUI \& Research and Content writer Dr. Moeed Pirzada's team at GNN-TV.

$*$ M.Phil-IR graduate from IIUI.
} 
purely a source of encouragement for the major power players to initiate peace in the world. The first and foremost factor of the Old Cold War was ideological differences. Hegemony over the world and economic superiority were the second most important factors in that chaotic war. In the New Cold War there is a minor change in these factors, it is not based on ideology but economic superiority and hegemony over the world are most important factors. It does not make any sense to state that Russia has become a common power and the expansion of NATO is not concerned with the Russian federation and the re-emergence of Russia.

NATO made USA a super power and the same NATO is getting stronger by being expanded, only to safeguard the hegemony of USA in the world. Rising China has become another worry for the supremacy of USA in terms of economy. Russia is creating many disturbances for the primacy of US in the world in different ways. Russia attacked on Georgia in 2008 and later on its annexation of Crimea and its support for Syria and Iran became some vivid symbols of Cold War.

Many writers view these activities of such great powers like USA, very optimistically and they refuse the advent of a new Cold War, even some refuse the terminology of New Cold War. Writers like Stephen kotkin called it a Myth of the New Cold War (Kotkin, 2008). This is an optimistic view of the world politics, but in reality a New Cold War has been started after the end of Cold War 1. Writers like Edward Lucas have expressed their views about a New Cold War in a bold manner. Many American writers try to undermined Russia and New Cold War only because they have lost much more in the first Cold War. The word Cold War has become a night mare for Americans who witness the first Cold War very closely.

Russia's intervention in Syria has generated many questions in the intellectual circles. Putin acts as Stalin in the war against rebels of Syria. In the post-Cold War Russia has intervened in a foreign territory for the first time in a continent very far from Russia. Russia's presence in Syria poses many threats for the supremacy of US and NATO forces in the region. US criticises the airstrikes of Russia in the region severely. European world and NATO countries are suspicious about the hegemonic designs of Russia in this region. Turkey and Russia are near to fight a war which will bring the NATO countries to fight against Russia.

All those variables, which cause Cold Wars are clearly seen in the modern days. There are some changes in these variables. In this article, all those variables, which are chiefly responsible for Cold Wars are expressed in detail. The expansion of NATO and US policy to counter Russia would be analysed deeply. Chinese security ties with Russia, which make Russia a powerful state and China's ties with Russia are also aimed to counter the hegemony of US in many regions of the world. The cooperation of rogue states like Iran and Syria with Russia would be elaborated in a New Cold War perspective and Russian policy of collective security with the expansion 
of SCO would be discussed. Although SCO was not made during the Old Cold War but it was designed after the end of First Cold War, China was a US ally during the Cold War and it left US and joined Russia through many security treaties and blocs. Finally, it would be concluded.

\section{Historical Background}

USA appeared as a world power in the late $20^{\text {th }}$ Century, during the initial years of Cold War I. Soviet Union was already a leading power in the international community. Prior to that both USA and USSR were considering Germany a common threat for both of them. Both become allies in the Second World War. Bipolarity after second World War was the greatest reason which dragged both of these great powers to hatch conspiracies against each other for hegemony, dominance and above all, for the victory of ideology. USA, with the help of Western powers became a greatest proponent of capitalism and Russia expounded about communism. This ideological clash remained for more than 45 years. In 1947, Bernard Baruch termed it Cold War. This Cold War took place without any accurate pronouncement. It was unbearable for both these atomic powers to fight a traditional war in this period because such a war would have been devastated the whole world. They never confronted each other directly but generated tensions for each other in many fronts. Cold war was fought in different phases.

Gorbachev, the last president of USSR introduced his famous policy of Perestroika and Glasnost. He was the chief character to end the Cold War. Many Russians still do not admit USA as a super power. Francis Fukuyama presented his thesis with the idea of "The End of History" and S.P Huntington presented the idea of Clash of Civilization. The end of history is in fact, the starting of a new history. Clash of civilization was considered as the most ambiguous theory in 1992, but later on it became the most popular, famous and most discussed theory in social science circles when USA started war in Afghanistan and Iraq. Clash of civilizations is one prediction of New Cold War in future. For Huntington, the future of the world would be the Clash of Civilization (Huntinton, 1996).

Russia has never accepted USA as a super power in the past and still it do not agree to take her as a supreme power. From 1990 onward, Russia has taken a pace to build its war torn economy. Alliances like SCO, Shanghai cooperation organization, Collective Security Treaty Organization, BRICS and Eurasian Union shows that Russia is trying to restore its lost glory through a second Cold War.

After 9/11, it became crystal clear that a Second Cold War has been started. USA attacked Afghanistan in the name of war on terror. US stayed in Afghanistan like a bad guest who has forgotten to leave. When Soviet Union attacked Afghanistan, USA has stayed here in Afghanistan for more 
than 15 years. USA is ready to construct a New Silk Route in Afghanistan and this will be a great setback for the economy of PRC and it would be a direct threat to Russia.

USA fought war with Iraq and Syria, both of these powers always considered China and Russia a counterweight to USA. The idea of New Great game by Lutz C. Cleveman presents that USA and Russia are busy in the New Great game to maximise natural resources.

The second phase of Cold War which has been started by USA and Russia is different from the first Cold War from 1945-1991, in nature. The firstCold War was ideological and the new phase of Cold War would be the war for hegemony and economic supremacy. It is not necessary that only ideological clashes can lead a Cold War, but in an atomic world a direct confrontation has become impossible so Cold War has become a way to acquire the gaols of major States.

\section{Sino-Russian Relations}

\section{a) Sino-USSR Relations During Cold War}

Communism was the main binding force between PRC and USSR during the initial years of the Cold War. China became Peoples Republic in 1949 and cooperated with USSR. Both PRC and USSR became strong contenders of capitalism in the world. This relation was an alarmingly dangerous sign for the destruction of growing capitalism in the world particularly in Asia. This relation was viewed by Washington as a grave threat. In 1950 China supported USSR by joining the communist bloc. The hegemonic designs of USSR in Asia sabotaged the relations of PRC-USSR in 1969 through a clash. This Clash weakened the Eastern Communist bloc. US took full advantage from this destructive scenario. US come closer to China and then they became common rivals of USSR. This golden chance provided many opportunities to US to propagate capitalism and contain communism in Asia. China and US conjoined in many fronts but some differences remained unsettled between these two countries till the end of Cold War.

\section{b) Sino-Russia Relations in the Post-Cold War}

In the post-Cold War era again China came nearer to Russia. China's deep rooted relations with Russia took new roots. The mutual assertion on the multipolar world and a new world order sign up by Beijing and Moscow in April 1997 proposed the kind of strategic joint partnerships that are expected to improve in an environment of horror in the future, as well as the most likely reasons why such coalitions may be forged between nations that have undergone from bitter relations in the recent past (Wittkopf, 2004). Although China had close relations with the US during Cold War, but some issues remained unsettled between the two like Taiwan issue and China's 
cooperation with Rogue States. China became a fast rising power in the East and it started good relations with Russia for the revival of its Old relations with Russia.

Post-Cold War relations between Russia and China became stronger day by day after 1992. Joseph Nye stated that after the breakdown of USSR China terminated her de-facto alliance with the US and enhanced her relations with Russia and the two nations pursued "constructive partnership"(Nye, 2015). Both states took special interest in establishment of blocs of cooperation. They formed Shanghai five, in 1996 later on it became SCO. They formed Eurasian Union and BRICS in 2009 to cooperate economically. This growing relation was viewed by west as the preparation for a new Cold War. PRC and China became highly concerned about the Central Asian Republics. Their cooperation in the post-Cold War is much stronger than that of the initial years of the Cold War. Being communist states, they share a huge cultural similarity along with physical proximity. Cultural similarities and physical nearness with some common goals have brought these nations much nearer to each other. The current stronger bond between these two states signifies that they are busy in a new Cold War with USA.

Both these states share a common view about mutipolarity of the world, which challenges the US supremacy in the world. Both are cooperating with different powerful states in Asia like Pakistan, India, Iran and North Korea. Making a stronger Asia has become the dream of both these communist countries. Both are empowering rogue states in the world. Thus the cooperation of PRC and Russia have reached to such a high point that they are about to respond to a common threat combine. These two countries possess superior military and defence equipment and a higher military budget. It has become a bloc to counter the hegemony of US in the world. This bloc is not in a position to compromise with any hegemonic power, when they see any threat against the interest of their Bloc.

\section{Expansion of NATO}

NATO was formed by United States to fight against the Domino effect of communism in the world particularly in the European continent. NATO achieved almost it's all goals till the end of old Cold War. War saw pact was dissolved but NATO was expanded just after the end of Cold War I. The expansion of NATO in a unipolar world generates some serious questions about world Politics. Why was NATO not dissolved after achieving a myriad number of goals? USSR was a potential threat for the hegemony of US in the world that's why treaties like NATO were formed. Is there any potential threat for the superiority of USA in the world?

From $30^{\text {th }}$ October 1990 German re-unification to $1^{\text {st }}$ April 2009 almost twelve different European countries like Czech Republic, Hungary, Poland, 
Bulgaria, Estonia, Slovenia, Slovakia, Albania and Croatia became part of this grand treaty which was aimed to curtail communism in Europe. After Cold War, NATO became much powerful organization with a rapid expansion. This hasty expansion of NATO displays that Cold War is not over, it was just a pause after 1989. On the other side Russia is not hushed on this expansion. The peak distinguished expert on this matter, previous Russian president Michael Gorbachev, has criticized that the West ruined its candid assurance not to enlarge NATO (Joseph, 2014). After first Cold War, USA played a Machiavellian duplicity with Russia. Although Secretary of State James Baker had promised President Gorbachev during German ReUnification in early 1990 s, where it was vowed that NATO would not take in East Europe but Germany was made a member of NATO (Rozoff, April27,2013).

\section{Russia and Iran Cooperation}

Iran was the most allied ally of USA during the tenure of Raza Shah Pehlevi. The revolution of 1979 transformed everything. Iranian revolutionaries shunned relations with United States. USA lost a closest friend of it in 1979. Proximity to the previous Soviet Union and its being an adversary of USA, Soviet Union engrossed Iran to maintain good relations with Moscow. Iran became a great challenge for USA in the region. Later on, Iran started cooperation in nuclear technology with Russia (Peet, 2015). That was a huge fear of USA about Iran. The cooperation of Russia and Iran in many fronts displays that Cold War is not yet over but it's still there. Despite sanctions, and despite its international status as a rogue State Russia sustained its backing in many spheres with Iran. Although the cooperation of Russia with Iran is in many areas but some spheres like Military Cooperation, nuclear cooperation shows some perilous signs of Cold War.

\section{a) Military Cooperation}

USA is trying to de- militarize and non-nuclearize Iran. After 1979 USA used many tactics to make Iran a normal state but still Iran contemplates USA its greatest adversary. Iran always tried to look towards East to make itself a powerful state in the region. Closest relations with China and Russia are the dream of Iran to counter the hegemony of USA. It is virtually third major trader of Russian weaponries. Russia has permitted Iran to formulate missiles for its own use. (Koolaee, 2008)

In such a period when every nation of the globe has no courage to make relations with Iran without the approval of USA, Russia signs contracts with Iran. On $20^{\text {th }}$ January Iran's Hossein Dehghan and defence minister of Russia Sergei Shoigu signed an agreement "long term and multifaceted" collaboration of military in Tehran. In such a situation, when Iran is fronting different kinds of sanctions and it has been isolated from the world politics. 
According to associated press Hossein Dehghan articulated his opinion to halt US involvements in the region Iran-Russian military team work would be a combined struggle" (Gady, 2015). This move of Russia makes it clear that it does not need any approval from the super power. This also displays that Russia do not reflect USA a super power and hegemon of the world.

\section{b) Nuclear Cooperation}

Russian cooperation with Iran is not limited to defence agreements. It has developed relations with Iran in other complex fronts too. Nuclear cooperation of the two countries without the consent of super power in a Uni-polar world is in fact the declaration of a Cold War. Russia is making her neighbours resilient to resist USA. In 1998, December Clinton administration blamed Russia that it is violating an agreement with the USA not to afford its nuclear reactors. US's objection was very much clear when Russia cooperated with Iran on the Bushehr reactor. Moscow was also blamed of aiding Iran for the making of heavy water and graphite. US supposed both Russia and China for providing backing to enhance Iranian Nuclear capability. (Ahrari, 1999) "The United States has already "substantially curtailed cooperation with key Russian nuclear facilities as a result of the Iran transfer."(Gertz, 1998) In the recent skirmishes in the Middle East the stance of Iran, Russia and China is clearly against Western powers. Western world is in favour of attacking rebels in Yemen. Saudi Arabia is leading the coalition of Middle Eastern states like Jordan, Egypt, Sudan, Kuwait, Qatar, Bahrain, and UAE and western powers like UK, USA and France are backing these strikes. The position of Iran is clear in this chart. This stance of Iran shows that it will be a strong ally of Russia when in future USA is fighting any type of war with Russia.

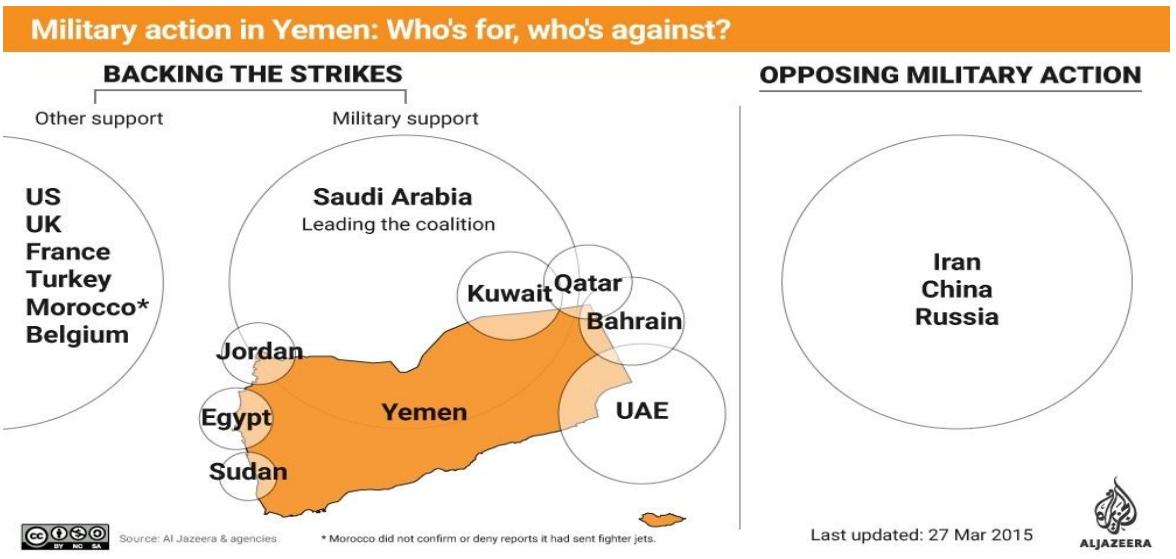

Source: Al Jazeera News 


\section{Russia's Treaties and Alliances}

The expansion of NATO fuelled Russia to ponder about different combined security treaties, as in the first Cold War, Warsaw pact was made in response to the establishment of NATO. NATO's enlargement compelled Moscow to think about the establishment of Shanghai Cooperation Organization. The second biggest economy of the world like PRC is an active member of SCO. This organization has become the greatest cause of convergence in the Sino-Russia relations. Russia became active in economic treaties like BRICS, Eurasian Economic Union and security treaties like Collective Security treaty Organization and SCO. Currently SCO has 6 members, China, Kazakhstan, Kyrgyzstan, Russia, Tajikistan, Uzbekistan, India, and Pakistan. "In 2005 at the Astana summit of SCO told Washington to tell the final date of withdrawal from the bases of Central Asian Regions. Russia and China did a lot of military exercises to show the authority of SCO comparable with the NATO."(Vladimir, 2011)

Collective Security Treaty Organization CSTO is an intergovernmental military alliance which was signed on 15 may 1992 by six post-Soviet states like, Russia, Armenia, Kazakhstan, Tajikistan and Uzbekistan, which is also called "Tashkent Pact" Azerbaijan, Belarus and Georgia. In 2002 six States became part of collective Security Treaty Organization as military alliance.

BRICS is an association of major emerging national economies like Brazil, Russia, India, China and South Africa. Both Russia and China will try to make BRICS as a permanent member of SCO. After 2010 with the inclusion of South Africa these countries met in formal summits. In 2014 according to IMF BRICS is the representative of $40 \%$ of the world population and it has a $20 \%$ of the world's GDP (IMF, 2013).

If USA has become a super power after the end of Cold War then Russia has not been a mute spectator in the world politics. Alliances and counter alliances are made by these two powers after the first Cold War. Cooperation of Brazil with Russia is a huge question mark for USA in the American landmass. The establishment of SCO, CSTO, BRICS and Eurasian Union has strengthened Russia once again and it is not worth undermining for USA. According to many writers Russia is gradually becoming a normal country but how it is possible for a normal country to make such powerful blocs. Russia is an active player in all these organizations like BRICS, CSTO, SCO and Eurasian Economic Union. If USA can be a hegemon of the world having a strong NATO then Russia also can be a hegemon of the world by giving permanent memberships to BRICS and CSTO in SCO. SCO has all that potentials which NATO has. Through SCO, Russia can do all that which USA is doing with the help of a strong NATO. 


\section{Crimean Crisis}

Crimean crisis is one of the greatest testimonials of a Second Cold War. Russia recuperated its former territory in March 2014. In this case the expansion of NATO gave rise to the expansion of Russia itself because NATO's extension made Russia responsive. USA exasperated to cooperate with all those states which were parts of the Soviet Union in Central Asia and Ukraine. US intervention in the affairs of the states of Soviet Union invoked Russia to expand itself to compete with USA. (Legvold, 2014).

Edward Lucas a Western writer termed the skirmishes of USA and Russia as "The New Cold War" he says that his short hand term for the new age of anxious conflict between the West and Kremlin is "The New Cold War." (Lucas, 2008) Lucas says that the world is doing a great mistake by considering Russia a "Normal Country", for him Russia is not a normal state it is mounting slowly but surely and it can be the prime intimidation for the hegemony of USA in the world. "The most calamitous blunder the external world has done since 1991 is to undertake that Russia is gradually becoming a "normal Country."(Lucas, 2008)Michael Slobodchikoff, a professor in the political science department at Troy University said "We are at the start of a new Cold War" there is little well-adjusted analysis of the circumstances, and neither side wants conciliation. The fight over Ukraine is a "high stakeszero-sum game" that neither side can pay for to lose. Both sides seem to be eager to intensify this skirmish into a New Cold War. (Koshkin, 2014)

Chicago Council on Global affairs shaped a report in February, the Atlantic council and the Brooking institutions pressed USA to provide Ukraine self-protective weaponries and \$3billion in martial aid over 3 years in an attempt to put off Russian hostility in Eastern Europe (Ivo Daalder, 2015). In the name of humanitarian intervention and humanitarian aid US is hatching conspiracies in the territories of Soviet Union to weaken Russia.

\section{Russian Involvement in Syria}

Russia intervened for the first time in a foreign territory after the end of first Cold War. China was also seen contributing militarily in a foreign territory. Syria was an old ally of USSR during the Era of Cold War. It has multifarious dealings with PRC and Russia. Syria is the biggest partner of Russia and China in the Middle East which disapprove the Unipolarity in the Middle East. There was no longer an exclusive domain under the supremacy of the US and its partners. (Seale, 2012)

US tried to throw out Assad regime from Syria and supported rebels to topple the regime of Assad because Assad was projecting anti-US sentiments in the Middle East and he was cooperating with Russia and China by considering them counterweight to US Supremacy. US could not be successful in Syria because of the Support of Russia and China to Assad 
regime. Russia and China has hitherto rejected three anti-Syrian resolutions projected to the Un Security council by Western nations (Sanaei, 2012).

China was an ally of US in the Cold War but after Cold War it started to strengthen her ties with Russia to challenge the global unipolarity of US in the World. China believes in a peaceful development policy but their activity in many regions depicts the reality that it too has some imperial mindset. She also wants to meddle in the affairs of the world. China has also installed its "Carrier-Based Fighter Aircraft Shenyang J-15" in Syria (Tikonova, oct 2015) China has a good trade relation with Syria, it sails weapons and imports energy resources from Syria (Hall, 2015).

Russia has multifaceted goals in Syria but her critical objective in Syria is the safeguarding of Assad administration. If Assad goes, Putin loses his only naval base in the Mediterranean Sea at the port city of Tartous (Coffey, 14 sep 2015.) Naval bases in the Mediterranean Sea are strategically important for Russia to counter the expansion of NATO and US primacy in the region. Russia's involvement in the region is a strategic goal and not a humanitarian cause. For the purpose of regime change, US supported rebels in Syria and the same rebel groups became threat for the peace of the whole world in the form of ISIS. Russia had already warned that the interference of US in Syria would be disastrous (Radia, August 2013). ISIS has become a threat for the peace of the world and it attacked in a peaceful mob in France and in US in November 2015. This group has threatened to attack on Europe and the United States. Abu Baker Baghdadi was a penitentiary in the jail of US later on he was released and he mobilized rebel groups and created a self-made Islamic State (ISIS) in the name of revival of Khilafat in the Middle East.

Syria is also one of the biggest business partners of Russia and China, Both Russia and China has deep interests associated with Syria. Syria considers Russia and China to counterpoise the supremacy of the US in the region. The strategic location of Syria further attracts the two states to cooperate with it.

\section{Conclusion}

Cold War is not over; but it has entered in its second phase and this phase is called Cold War II. USA always tries to undermine Russian activities, but an anxiety in Washington about Russian re-emergence is still prevalent. If USA is a superpower of the world; then Russia is not a normal power. If a strong NATO guarantees the status and superiority of USA in the world; then surely an emerging SCO will uplift the status of Russia. The idea of the end of Cold War is a good idea for those international political scientists, who view the world in a highly optimistic manner. Russia is trying to make it economically strong by signing agreements and by joining blocks like Brazil, Russia, India, China and South Africa (BRICS), Eurasian 
Economic Community, and SCO to make it enable to compete with the hegemony of USA. Russia's strong bonds with China, its amiable ties with rogue states like Iran, North Korea, Syria and other states is a clear signal and witness of New Cold War. In October 2014 when USA was bombing Syria, Russia replied in this way; "The officials said Russia warned it could potentially retaliate if US or Arab air strikes go beyond targeting Islamic State of Iraq and Syria or ISIS, and instead bomb any Syrian regime target."(Klein, 2014)

Both Powers are full of activity in their arrangements and engagements. USA is busy to maintain its superiority in the world which needs a great toil to uphold it. USA is spending a huge budget to acquire its goals internationally. USA lost its trillion Dollars in Afghanistan in the name of war for democratization. USA fought a bloody war with Iraq and currently it is fighting war in Syria and backing the fighters in Yemen. In Yemen Russia, Iran, and China's position is discernible and they are against of using force in Yemen but USA is backing Saudi Arabia in this war. All these spending of USA are aimed to maintain US supremacy all over the world. The expansion of NATO was made only to safeguard US interests in the world. US stance in Crimean crisis and its support towards Ukraine clearly shows that it is busy in the Second Cold War with Russia.

On the other side Russia is busy to compete USA in terms of hegemony and influence from the late 1992-2015, Russia has kept herself busy in such activities, which are seriously prohibited in a unipolar world. Participation in different agreements and its clashes with Georgia and Ukraine after first Cold War and its most recent stance about US air strikes on Syria and Yemen shows that it does not consider USA a super power. Its involvement in Syria to secure her strategic goals further clarifies her hegemonic mindset and above all, Russia still consider the existence of multipolarity in the world and it rejects Unipolarity of the US. US involvement in Syria is another solid proof of a new Cold War, the interests of Russia and China in Syria has a clash with the interests of US in Syria. First time in the history, in the post-Cold War era, Russia and China are sending their troops in such a far foreign territory. Involvement of China with Russia confirms the reality that both Russia and China are allies and they are fighting a Cold War with US superiority in the Middle East.

In fact China and Russian standpoint about different global political occasions and their preparation for the acquisition of hegemony over the world has generated a horror in Washington. The year 2015 is witnessing some new vicissitudes in the attitude of US towards some Russian and Chinese favoured states like Cuba and Iran. Aljazeera says that "It was the first time the chief diplomats from the two nations met since 1958; one year before Fidel Castro's revolutionary guerrillas came to power".(Aljazeera, 2015) USA has also signed a nuclear deal with Iran to weaken Iran, China and Russia Nexus according to the same news channels. This shows that 
USA is fearful about the policies of Russia and China because Cold War is over; Cold War is there.

\section{References}

Ahrari, M.A. (1999). The beginning of a New Cold War. European Security, 131.

Aljazeera. (2015).

Coffey, L. (2015). Could Syria be Putin's Afghanistan? Aljazeera.

Gady, F.S. (2015). Russia and Iran Sign Military cooperation Agreement.

Gertz, B. (1998). US Accuses Iran of Backing Nuke Pact. Washington Times.

Hall, J. (2015). Putin threatens Nuclear War: Russian leader will take any necessory step to drive NATO out of baltics and defend Crimea. Mail Online.

Huntinton, S.P. (1996). Clash of Civilizations.

IMF. (2013). World Economic outlook.

Ivo Daalder, M.F. (2015). Preserving Ukraine'sIndependence, Resisting Russian Aggression: Brookings: Atlantic council.

Joseph, E.P. (2014). NATO Expansion: The source of Russia's Anger. The National Interest.

Klein, A. (2014). Russia Threatens to Retaliate against U.S military. WND.

Koolaee, E. (2008). Iran and Russia. Conference on Russia and Islam. Edinburgh: University of Tehran.

Koshkin, P. (2014). Will Crimea Crisis LEad to Cold WarII. Russia Direct.

Kotkin, S. (2008). Myth of the New Cold War. Retrieved from Scholar. princeton.edu: Myth of the New Cold War/kotkin/publications/mythNe-Cold-War.

Legvold, R. (2014). Are US and Russia in a New Cold War? VOA News.

Lucas, E. (2008). The New Cold War. Newyork: Palgrave macmilian.

Nye, J. (2015). A new Sino-Russian Alliance. Project Syndicate.

PEET, J. (2015). Living With A BEAR. The Economists, 95.

Radia, K. (2013). Russia Warns of Catatrophic Consequences if US meddles in Syria. $A B C$ News.

Rozoff, R. (2013). NATO's World Wide Expansion In The Post Cold War Era. Global Research.

Sanaei, M. (2012). Russia and New Cold War in Syria. Iran Review.

Seale, P. (2012). Syria and the New Cold War. The Diplomate. Retrieved from thediplomate.com

Tikonova, P. (2015). US Russia Cold War Begins in Syria: Chinese Paper. Value Walk.

Valadmir, F. (2011). Russia and China want Pakistan and India in SCO and USA Rejected. Pakistan Defence.

Wittkopf, C.W. (2004). Word Politics. United States: Clark Baxter. 